Article

\title{
Systematization: A Key Term in 20th-Century Romanian Urbanism
}

\author{
Dana Vais \\ Department of Architecture, Technical University of Cluj-Napoca, Romania; dana.vais@arch.utcluj.ro
}

Submitted: 5 August 2021 | Accepted: 24 November 2021 | Published: 31 March 2022

\begin{abstract}
This article addresses the term "systematization" as it was used in Romania during the 20th century. It investigates the sources of the term and the changes in its meaning and in the practice it named in each phase of its evolution: from its emergence at the turn of the 20th century and its adoption as a label for scientific urbanism during the interwar period, to its political instrumentalization and projection on large scales in spatial planning during the late socialist period, and its rejection in the post-socialist years. It shows how a term can radically change its connotations, ranging from desirable to destructive effects. It exposes the variable distance between systematization as a concept and systematization as a concrete practice. The scientific and disciplinary aspects of systematization are addressed, highlighting its relation to the fields of architecture and urbanism. Its political relevance as an instrument for the authoritarian and respectively totalitarian Romanian state is shown, serving their interest to act on the territory on a large scale. Housing is also addressed as a central subject of systematization. The aim of the article is, first, to draw a history that apprehends the entire evolution, from emergence to dismissal, of a term that marked Romanian planning for a century; and second, to show that beyond its local history, this term is relevant for understanding the more general relationship between scientificity and political instrumentalization in modern urbanism and architecture during the 20th century.
\end{abstract}

\section{Keywords}

20th century; housing; modern urbanism; Romania; scientificity; socialist planning; systematization

\section{Issue}

This article is part of the issue "The Terms of Dwelling: Re-Theorizing Housing Through Architecture" edited by Yael Allweil (Technion-Israel Institute of Technology) and Gaia Caramellino (Politecnico di Milano).

(C) 2022 by the author(s); licensee Cogitatio (Lisbon, Portugal). This article is licensed under a Creative Commons Attribution 4.0 International License (CC BY).

\section{Introduction}

When the Romanian communist regime fell in December 1989, "systematization" was one of the infamous notions that had to be abolished, a pejorative term designating the destruction of villages, mutilation of cities, and razing of the center of the capital, Bucharest. This extremely negative perception, earned in the last years of the communist regime, was projected back onto a notion that had been used for many decades, and which most of the time had stood for progress and modernization.

In the general sense, "systematization" is a neutral technical notion. It refers to an act of organization that creates a rigorous order in the logic of systemsintegral structures of hierarchized interdependent components. It has been used mostly in contexts where it functioned at an abstract level (e.g., "systematization of knowledge"). In architecture and urbanism, introducing a systemic order into space was a rather common modern idea. However, the word "systematization" itself, in this context, was not at all common. Romania in the 20th century was one of the few places in which the term occupied a central stage in the conceptualization of spatial planning and design. Actually, there is no other country where the term made such a pivotal and enduring career. "Systematization" has been a key term in Romanian urbanism for almost a century.

It does not mean, however, that Romanian systematization was an exceptional notion. It was just an instantiation, albeit extreme, of the scientificity claim in modern planning. At its highest moments, systematization devised an order that was abstract and generic, and where geometric regularity prevailed over real territories. The fascination for perfect spatial symmetries, along 
with borrowings from hard natural sciences like biology, had an enduring place in modern planning. Historian Eric Mumford (2018, pp. 197, 257-259) showed that biologist Ludwig von Bertalanffy's "systems theory" has reached a worldwide audience, notably through works like Walter Christaller's in the 1930s, and its principles were applied through various formal regulations, before and after World War II. By the mid-1970s, Alexandru Sandu, professor of urbanism at the Ion Mincu Institute of Architecture in Bucharest, explained the systematization of urban and rural localities, which had just been formalized into law, by referring to, among others, Walter Christaller's geometric networks of dispersed centralities (Sandu, 1974, p. 52). Romanian systematization was inspired by "systems theory" and was part of the hard scientificity trend in modern planning. Its evolution into an instrument for the political regime to enforce a total abstract order upon the real territory was intrinsic to its very logic of systemic thinking: This is what this article claims.

The notion has been studied before in the Romanian context, but only in partial perspectives and for either interwar or socialist periods. The purpose of this article is to develop a long-time perspective and draw the story of the term systematization over the entire period it was in use in Romania, from adoption to rejection, following the transformations of its meaning throughout this evolution. The research is mainly conducted on historical published materials-lexicons, school and professional manuals, articles, and books of the respective periods. It dwells upon the writings of selected personalities with authoritative influence on urban theory and practice at their time, who articulated a reflection on the notion of systematization. Eventually, Romanian history is also related to larger contexts, to show the relevance of this case study for the wider story of the notions of scientificity in modern planning.

\section{Pre- and Inter-War Systematization}

\subsection{Emergence of the Term}

The idea of spatial development was conducted systematically, and its appropriate terming emerged in Romania during the late 19th century. For instance, in 1883 the Forestry Act authorized the Ministry of Agriculture, Industry, Commerce and Domains to hire foresters from abroad. They were expected to make several "systematic plans of development" (planuri sistematice de amenagiament) of forests, to serve as practical learning grounds for the students of a new school where forestry was taught scientifically (Ministers' Council of Romania, 1903). The word "systematic" meant that the forest would be developed with a method, which could be imported as foreign expertise and taught in formal education as scientific knowledge.

This systemic approach did not concern urban environments at the time. Romanian cities were endur- ing significant modernizations, but these were rather disparate interventions-boulevards, squares, streets, buildings - the city being their mere background. Urban regulations epitomized the liberal interests of the bourgeoisie, for whom urban space aesthetics were important, but freedom of individual developments prevailed over administrative limitations. Bucharest, for instance, was described as a municipality totally deprived of regulatory power (Berindeiu, 1891) and many accounts depicted Romanian cities as utterly chaotic.

The first official use of the term systematization in an urban planning context in Romania occurred in the competition call for a "general plan of systematization" for Bucharest in 1906. The word was so new that in the competition brief the spelling was still uncertain; both "sistematisare" and "sistematizare" were used (Primăria Bucuresci, 1906). The text mentioned "the systematization of streets," explaining they should be organized in a hierarchical system, and "the systematization of the city," meaning the city would be treated as "a harmonic whole" (Primăria Bucuresci, 1906). This was the first attempt to take a holistic view of the urban development of the capital. However, the final contribution of this competition consisted in the introduction of the term only. The resulting plans were considered unsatisfactory, and they were moreover lost, along with the city archive, during the German occupation of 1916-1918 (Davidescu, 1941, p. 172).

Once emerged, the term began to be used also in reference to older city plans, designating more or less coherent previous attempts of putting order into the organically developed Romanian cities. The 1855 plan for the city of Focșani was a "veritable systematization plan" and so was the "Bucharest systematization plan" from 1885-1887 (Sfințescu, (1933a, pp. 79-80), although the word had not been used at those times: avant-la-lettre "systematizations" appeared in hindsight.

\subsection{From Term to Method}

The most important role in introducing and strengthening the term belongs to urban engineer Cincinat Sfințescu, "the father of Romanian urbanism" (Udrea et al., 2015, p. 6). He defined city planning as "a scientific procedure where you look to establish the relationships that exist, should exist, between the whole and its elements" (Sfințescu, 1916, p. 2). He also pleaded for "borrowing from foreign countries" (Sfințescu, 1916, p. 17) the notions of urban practices that were lacking in Romania.

Sfințescu (1933a, p. 86) was the author of "the first general project of the systematization plan" for Bucharest, decreed in 1921. Apart from holding office in the city administration, he also held the chair of urbanism at the Architecture Academy in Bucharest, which presented him with the opportunity to address the urban field as a rigorous discipline. He thoroughly researched the education programs and the practice of urbanism 
elsewhere. In 1931, for the International Federation for Housing and Town Planning in London, of which he was a member, he made an extensive report about the state of the discipline taught in the US, Germany, Switzerland, England, France, Poland, Holland, Spain-and Romania. The report was also published in Romanian (Sfințescu, 1932). Although the programs were exposed in detail in this survey, the term systematization was totally absent, as if it were not a necessary notion for the science of urbanism.

Whichever technique we use, Sfințescu wrote, we must establish the terminology first (1934b, pp. 1-2): In urbanism in general-"an eclectic science, as many other applied sciences"-and especially in which the Romanian language is concerned, the terminology is not yet settled. "I have collected 38 various names for urbanism," but all this wording, often arbitrary and partial, is only creating confusion in the discipline, he remarked (Sfințescu, 1933a, pp. 17-18). None of these many names for urbanism was systematization, but whenever Sfințescu referred to the context of practice, to actual examples of city plans, systematization seemed to be the preferred term. While describing the "regional systematization plan" (planul regional de sistematizare) of New York City and highlighting "the deeply rooted scientific spirit in American nature and organization today," Sfințescu used "systematization" to translate the word "planning" (Sfințescu, 1934a).

Indeed, the term was already well established in the language of Romanian professional practice and stood as a translation for a variety of other foreign terms. For instance, in reference to the competition for the Belgrade plan, the French "plan de réorganisation et d'agrendissement" was translated into Romanian as "plan pentru sistematizarea orașului" ("plan for the systematization of the city"; Bolomey \& Davidescu, 1924).

Until the early 1930s, the term was still vague and versatile. There were other terms in interchangeable use with "systematization," probably because there were many sources of inspiration. Sfințescu explicitly used "systematization" (sistematizare) as a synonym for several things-for "ordering" (a orândui), "regulation" (regulare), and "improvements" (ameliorări; Sfințescu, 1916, pp. 29, 62, 64)-but he also wrote about "improvement and systematization" as if they were two different things (Sfințescu, 1916, p. 62). He used "systematization" as a general term for the "mechanism" of urban transformation, but when addressing the Bucharest systematization project more specifically, he used the notion of "regulatory plan" (plan regulator; Sfințescu, 2015, pp. 43, 51).

A similar usage can be found in Italian. The Statute of the Italian National Urbanistic Institute of 1930, which was presented in extenso in Romanian in the journal Urbanismul (National Urbanistic Institute of Italy, 1932), employed the word sistemazione in a general sense, while the technical projects were officially named piani regolatori (Istituto Nazionale di Urbanistica, 1930).
Referring to an urban competition for piani regolatori in Italy, Sfințescu gave the translation planuri de amenajare in Romanian (Sfințescu, 1934a, p. 6), explaining that "'systematization' is a narrower notion comprehended within the sphere of the notion of amenajare" (Sfințescu, 1934b, p. 2).

So, systematization was both more general and narrower a notion and did not replace the other existing words that it sometimes doubled. All in all, systematization seemed not to be a basic-necessary and constitutive-term for urban planning, but rather a derivative one, designating a certain manner of addressing urban interventions; not a term of "what" but of "how," denoting the systematicity and scientific approach in planning.

\subsection{Architecture vs. Urbanism}

In the 1930s, architects took over the discourse on systematization from urban engineers. Sfințescu was an engineer directly involved in urban administration. Alexandru Zamphiropol, an architect and urbanist educated in France, came up with the sort of discourse characteristic to international architectural milieus. He drafted a systematization plan for Bucharest in 1931 (Figure 1) and offered it to the city council (Zamphiropol, 1934), apparently to no avail. For him, the leading idea was to define a clear modernist agenda: "The essential law of modern progress is the law of separation and specialization of functions and is imposed in the very structure of the city"; "the organization of the city has to assure maximum yield with minimum effort," he wrote (Zamphiropol, 1935, p. 4).

Indeed, modern architects at the time were just beginning "to learn the planning métier" (Domhardt, 2012 , p. 174), and by 1933 , for the fourth CIAM, they had developed the functional city concept. Although no architect represented Romania at the CIAM, many Romanian architects were educated in France and Germany and this kind of discourse appealed to them too. So, for Zamphiropol (1936, p. 4), urbanism did not mean alignments, some functional arrangements, monumental perspectives, and landscapes, "but to transform the city into a useful instrument appropriate to modern life." A distinction Zamphiropol made was between terms and method: "There are terms known today: urbanism, planning (amenajare), systematization, and other analogous technical expressions we have been familiarized with"; unfortunately, they were applied "without a well-defined method" (Zamphiropol, 1936, p. 4).

The main concern architects had was the ineffectiveness and uncertainty of systematization. In the early 1930s, they complained that Bucharest-supposedly the model for the entire country-was still transformed by "fragmentary systematization studies," while the general systematization plan was not yet enforced (Enescu, 1933). Architects would have preferred urban space to be controlled both overall and in detail. 


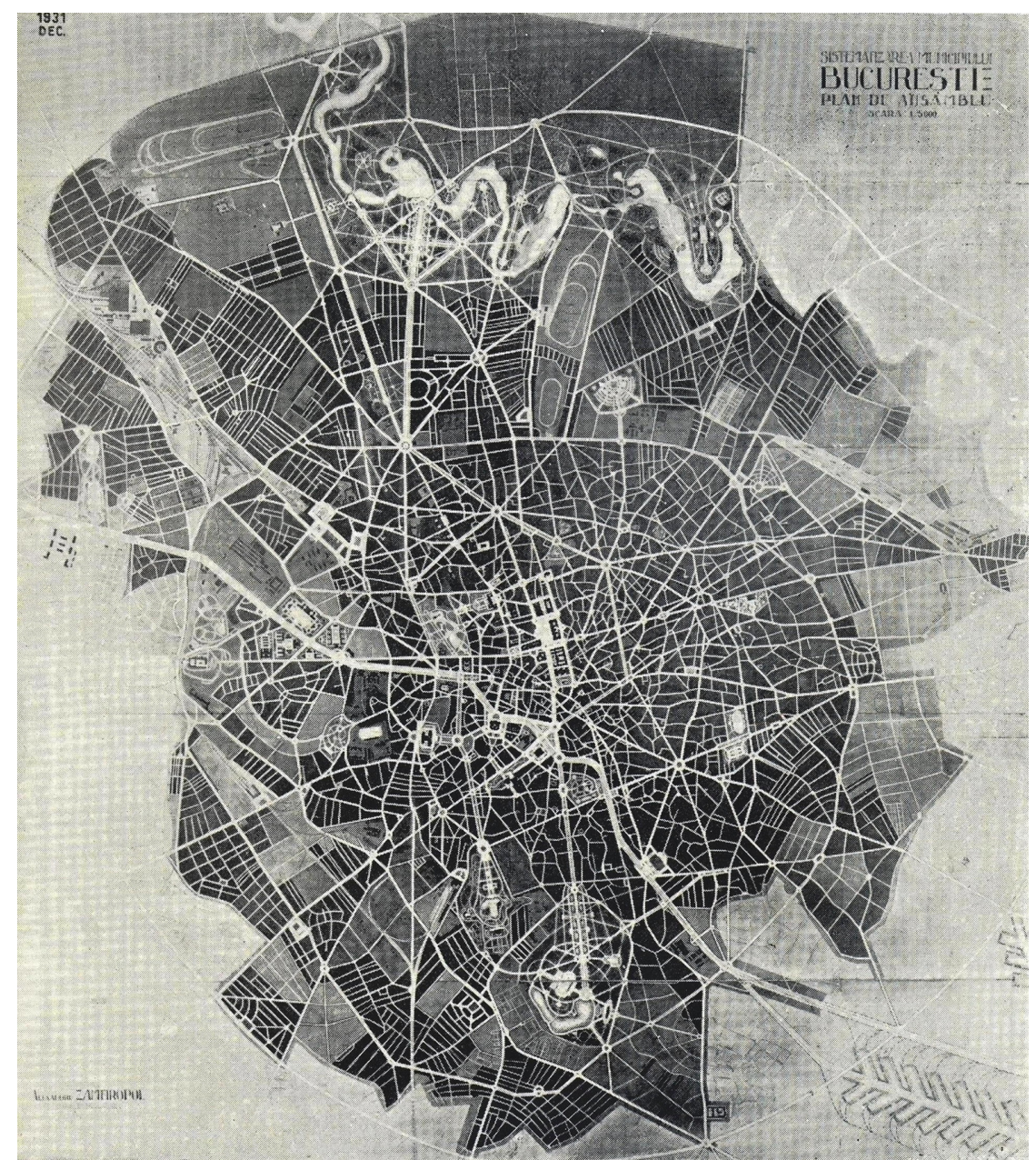

Figure 1. Alexandru Zamphiropol's systematization plan for Bucharest, 1931. Source: Zamphiropol (1934, p. 43).

Architects took the lead with the "master plan of systematization" (planul director de sistematizare) for Bucharest, decreed in 1935. Its authors were wellknown figures of the architectural profession: Duiliu Marcu, G. M. Cantacuzino, R. Bolomey, I. Davidescu, and T. Rădulescu (only the latter was an engineer). Their take on the notion of systematization reflected the general zeitgeist of the 1930s: "The organization of the city is an act of authority" (Marcu et al., 1937, p. 294). Either Bucharest becomes a capital that affirms the premises of authority and the will of organization, or it becomes a "monstrous disorder." But what do "the will of organization" and "premises of authority mean"? They are called "urbanism" (Marcu et al., 1937, p. 295).

\subsection{Housing}

The 1935 Systematization Plan for Bucharest also brought about a deeper focus on the housing problem, and specifically on housing for the poor (Figure 2). It does not mean the question had not been addressed before. Sfințescu (1933a, p. 71) had called housing

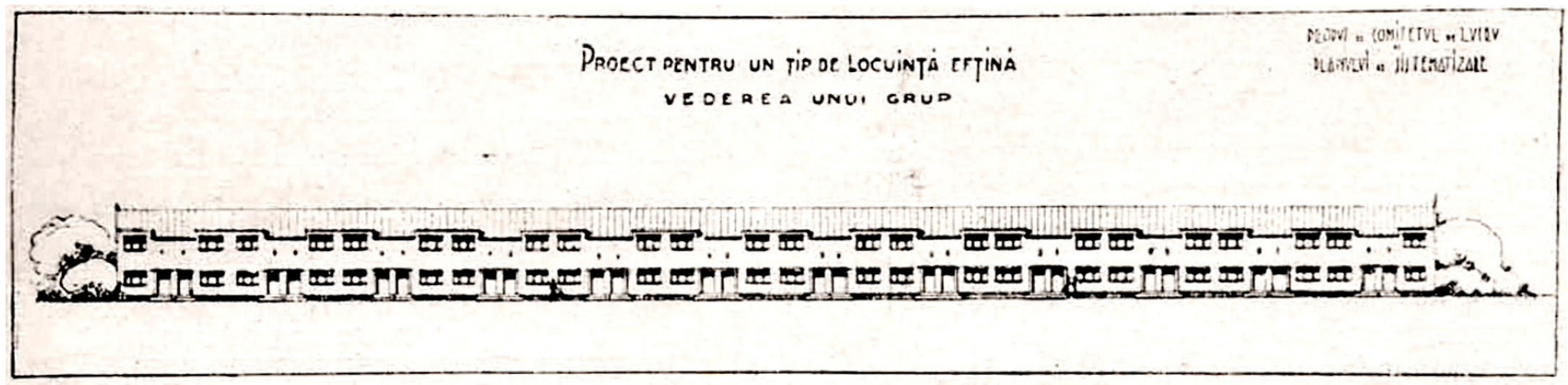

Figure 2. Low-cost housing project proposed by the "working committee" of the 1935 Bucharest Master Plan of Systematization. Source: Vîrtosu (1937, p. 68). 
"the main problem of present-day urbanism," which only a "pseudo-urbanism" could neglect. He praised the Communal Society for Low-Cost Housing (Societatea Comunală de Locuințe Eftine), established in 1911, for building "aesthetical and hygienic" new districts (cartiere; Figure 3 ) and called them "the practical urbanism of our times" (Sfințescu, 1933a, p. 86).

The study documenting the housing question for the 1935 Bucharest Systematization Plan showed, however, that in Romania this issue had been addressed very late, on a rather small scale, and that low-cost housing (locuințe eftine-literally "cheap housing") accommodated relatively better-off state employees (Figure 4). Urban peripheries remained truly miserable; $82 \%$ of the homes in Bucharest did not have a bathroom (Vîrtosu, 1936). The solution was to learn from the West. Recent "workers' housing" built in Vienna, Frankfurt, Rotterdam, or Berlin were presented in the Urbanismul journal and their typologies taught in courses on urbanism (Davidescu, 1936).
The problem was the distance between what was known and promoted in theory and what was actually achieved. Even though several laws - the Law of Administrative Unification of 1925, the Law of Local Administration of 1929 , and the Administrative Law of 1936-demanded all cities to devise systematization plans, few were actually made, and they all had difficulties in application (Davidescu, 1941).

\subsection{All-Scale Totalitarian}

At an abstract level, systematization could work at all scales. It emerged at the city level but was also scaled down to narrower objectives, e.g., a street or a square (Sfințescu, 1934b, p. 2), and up, to "regional systematization plans," addressing the surrounding communes in an area of interdependence with the city (Sfințescu, 2015, pp. 60-61). "By induction," even the "urbanistic organization for the territory of an entire state," "the rationalization of a country" was considered (Sfințescu,

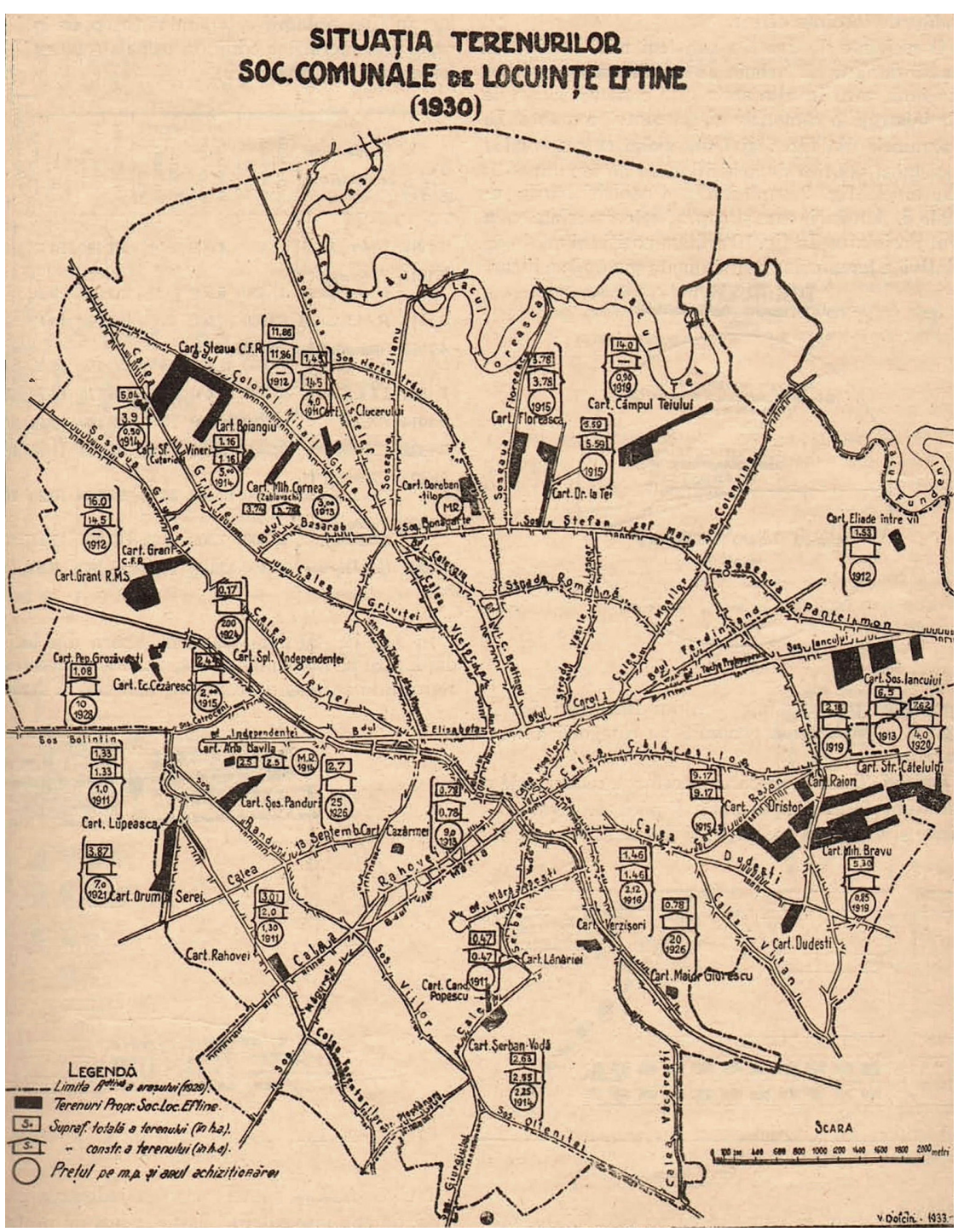

Figure 3. Plan of Bucharest showing the land attributed for parcellation to the Communal Society for Low-Cost Housing. Source: Sfințescu (1933b, p. 277). 


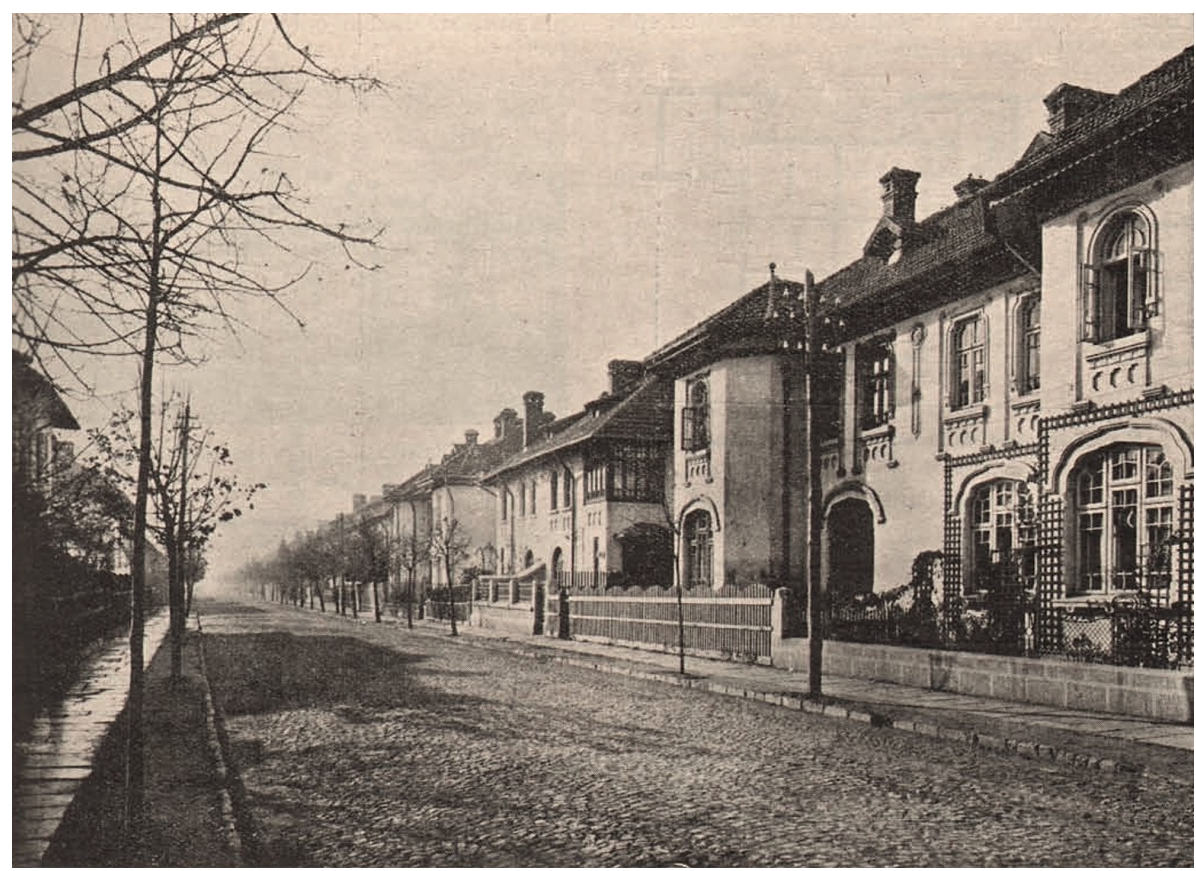

Figure 4. Housing built in Bucharest by the Communal Society for Low-Cost Housing before World War I. Source: Sfințescu (1933b, p. 283).

1933a, p. 294). For this largest scale, Sfințescu did not use the word systematization, although the idea of systematicity was inherent to it; he called it "superurbanism." The idea of "superurbanism" was essentially to transform the national territory into an integrated system. Cities were hierarchized as primary, secondary, and tertiary, and were imposed an "optimal urbanistic index" and "population ceiling"; the "optimal size of the city" was the "basic problem of superurbanism" (Sfințescu, 1933a, pp. 295-296).

Sfințescu (1933a) put the idea into the European context. Italy had a "national urbanistic plan equivalent to superurbanism"; "Russian superurbanism" aimed at the destruction of the old bourgeois cities and the creation of big new cities, and Germany promoted the return to villages. In Romania, urban density was too small, so adjustments had to be made. Sfințescu further developed the Romanian case in comparison, noting that his superurbanism was more than what Italians called "bonificare integrală" (bonifica integrale) or land improvement. It was also different from the "organizing action" in Soviet Russia. His superurbanism was closer to the recent Reichsplannung in Germany, "with which we find many similarities," sharing the aim of "rationally using the entire territory" (Sfințescu, 1934b, p. 98). It is quite relevant that, for radical interventions at a national scale, the best references found were the three main totalitarian regimes of the time.

Sfințescu called this approach "totalitarian" explicitly. Under the name of "national urbanism" and enacted "by totalitarian means," "superurbanism" was "one of the creations of the totalitarian style of our epoch" (Sfințescu, 1938, p. 341). In question was "the future of the nation" and "the future prevails over the present, just like the general national interests prevail over the local and the local over the individual" (Sfințescu, 1938, p. 342).

It was at the territorial scale that systematization seemed to work best. The Romanian state was still young in the interwar period, made up of regions with a very diverse history and culture. All plans of territorial organization, even those for interventions at smaller scales, were more or less bound for the idea of national integration. "Today we have to see far and wide," wrote the authors of the 1935 Bucharest systematization plan (Marcu et al., 1937, p. 299). They acknowledged the fact that what they "systematized" was the capital of Great Romania, the unified country that was no longer a state of eight million people, like before the Great War, but one of 18 million (Marcu et al., 1937, p. 299). The state pursued administrative unification and tried to increase Romanian presence in the newly acquired territories, where "minorities" prevailed.

Romania was also a predominantly rural country, and the population was not homogeneously distributed throughout its territory. These were motivations for the state to promote sweeping spatial reorganizations. Agrarian reform allocated expropriated land in ownership to peasants, which led to "village systematizations" and "new model settlements" (Stănculescu, 1925). These were followed by "colonization," "transplantation of peasants from regions with higher population density into regions with lower density, where free lots were available"-like "in Dobrogea, Cadrilater and on the Western border" (Rădulescu, 1941, p. 118). All these were "techniques of rationalization" achieving 
"the optimal usage of the national territory" and "optimal distribution of the population over the territory" (Sfințescu, 1938, pp. 341-342).

In the last years of Great Romania, during the so-called "royal dictatorship," systematization projects could be immediately realized, imposed by law with explicit instructions for application (Sfințescu, 1939). Typically, these projects were accompanied by detailed urban plans, including the creation of "civic centers" (Opari, 1939; Figure 5). Civic centers emerged during the 1930 s as part of systematization projects. The fact that they seemed more of a concern than housing in these plans attests to the interest of the authoritarian regime in being represented through architecture. To this end, and through this designed centrality, urbanism was architecturalized and aestheticized. Just before the end of the regime, this was the climax of systematization: full-scale control of the territory through dispersed centralities designed in architectural detail-a history that was to be repeated.

\section{Communist Systematization}

\subsection{Reviving the Term}

After the communist regime took power in 1948, the notion of systematization was adapted to the new imperative of socialist development. It was addressed by the Practicing Architect Handbook, edited in three volumes between 1954 and 1958, which contained "norms, design principles and technical solutions tested in practice during the grandiose process of constructing socialism and communism in the USSR" (T. Chițulescu et al., 1954, p. 13). Although the manual was intended as a vehicle for Soviet design concepts, the notion of systematization was reduced to its technical dimensions and not addressed in reflective terms. The concept was thus ideologically cleaned, to be made available for use in the changed political environment.

Systematization was presented as a "design method" and defined as a project category: "The projects for the
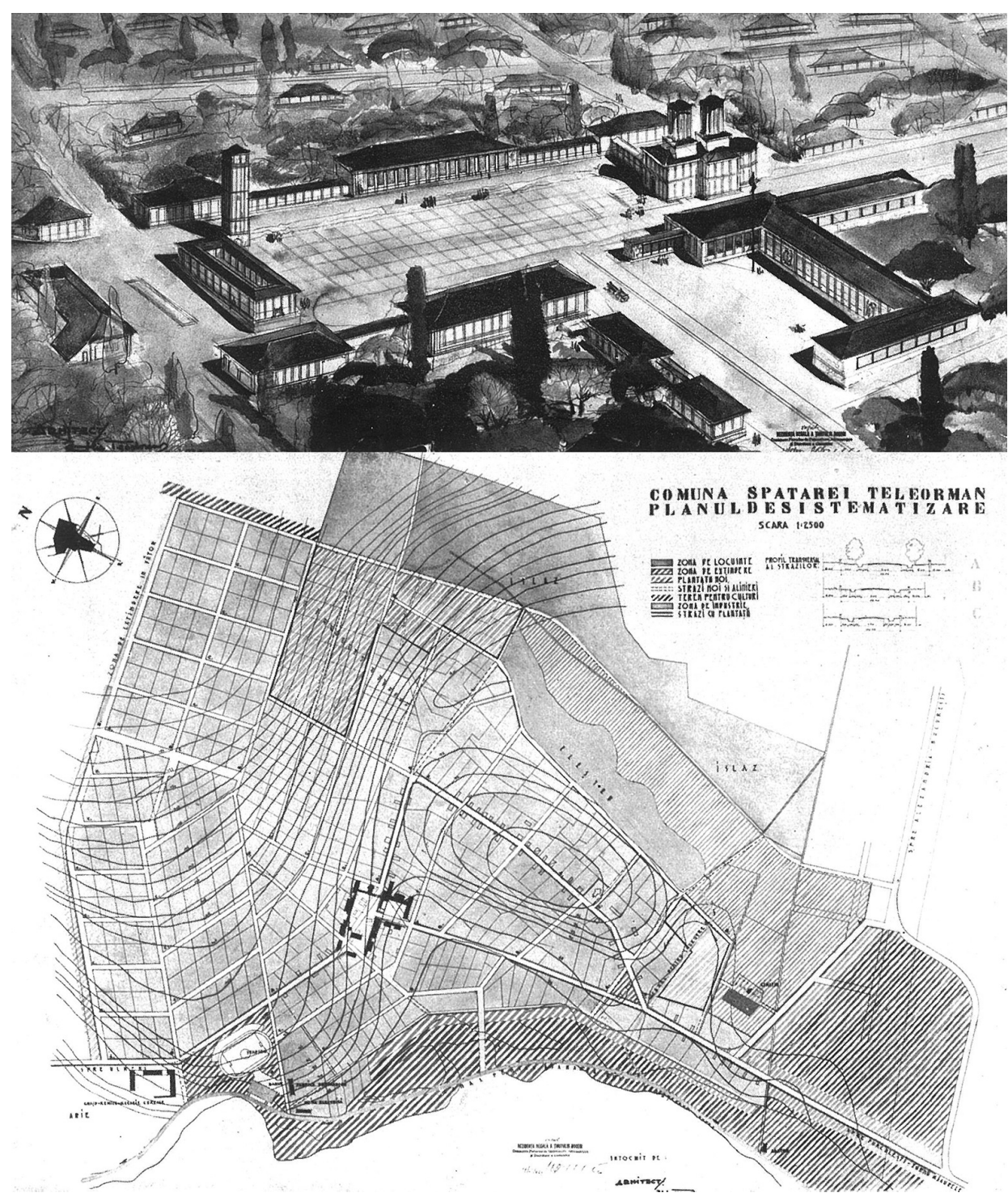

Figure 5. Systematization plan of a commune (Spatarei), including the project for a civic center. Source: Opari (1939, p. 10). 
construction of new cities and those of reconstruction and rational development of the existing ones bear in general the name of 'systematization plans' "; they could be local, territorial, or regional (T. Chițulescu et al., 1958, p. 305). The notion was deconstructed up to the point of losing its main idea; functions in the city were simply presented sequentially, not as elements in a system. Industry, housing, and green areas were detailed most extensively. A significant aspect was that industrial enterprises and localities were treated as equals in regional systematization. The distribution of new industry into the territory was even considered the first concern of regional systematization; the development of localities was made only after economic infrastructure (T. Chițulescu et al., 1958, p. 484). Industrial development took the lead in systematization.

Particularly important attention was given to rural systematization (T. Chițulescu et al., 1958, pp. 484-507). Romania was still a predominantly rural country and the issue of modernizing the village was of utmost relevance, especially as the co-operativization of agriculture was in full swing during the 1950s. Rural systematization concerned the creation of new villages and the restructuring of the existing ones, just like in the interwar period, except the neutral notion of "village center" replaced the civic center (T. Chițulescu et al., 1958, p. 498).

The coordinated organization of the entire territory of the country was addressed by territorial systematization, which determined the location, size, role, and profile of localities according to state economic plans. It avoided excessive concentrations and guided industrialization particularly towards underdeveloped regions, like Moldova and Oltenia (Spiride, 1959). The balanced distribution of "productive forces" throughout the national territory, in order to homogenize the unequally developed country, remained a major concern under the communist regime-like in "superurbanism" before. In many ways, the concept of communist systematization was a continuation of the one from the 1930s.

With the notion thus outlined, it was up to practice to really define communist systematization. The first application addressed the heavy industry centers, like Hunedoara, Galați, Ploiești, Iași, and Stalin City (Brașov), as well as seaside resorts (Locar \& Evolceanu, 1959). Resorts had been systematized by the previous regime too, but the industrial cities, the strongholds of the working class, reflected the priorities of the new regime.

The need for rapid applicability of systematization plans brought about a simplified notion: the "systematization sketch," which became mandatory for all cities in 1958. The "sketch" was a rather vague master plan, which had to be accompanied by other plans at lower scales. Its principle was that less detailing implied more flexibility and thus long-term applicability. In the kind of paradoxical argument that characterized the regime's rhetoric, this was presented as a new concept of "complex design," where all projects were drafted togethergeneral systematization plans and detailed systematiza- tion plans, but also investment plans, which were considered of outmost novelty and importance for systematization (Locar \& Evolceanu, 1959).

\subsection{Housing}

One major difference between interwar and postwar systematizations was the attention bestowed on housing. Mass housing development became the most important preoccupation, after industrial development, in systematization under the communist regime. Housing followed industrial investments closely throughout the country. The experience of the 1950s showed, for instance, that where new industrial investments were relatively small, about $25-30 \%$ of the employees had to be accommodated in new housing; where investments were big, new housing was needed for $40-50 \%$ of them (Spiride, 1959). From the introduction of systematization sketches in 1958 until around the mid-1970s, systematization plans would be almost synonymous with extension plans for large housing estates.

The housing estates built before 1958 had been conceived on smaller scales, in the socialist-realist style. The Handbook of 1958 (T. Chițulescu et al., 1958) was still illustrated with beautiful compositions of "cvartals." It was published at the very moment when this notion was abandoned, its concept being criticized as formalistic, unrealistic, "spectacular aestheticizing," preoccupied only with the monumental aspects, and eventually inapplicable (Locar \& Evolceanu, 1959).

The notion of "microraion" - another Soviet planning word, defined by the Handbook as the "component unit of the residential zone, immediately superior to cvartals" (T. Chițulescu et al., 1958, p. 349)-would be in use for another decade and prove to be more adaptable to the new low-cost imperatives. Interpreted in a less formal sense than the "cvartal" as a functionally complete urban unit, the microraion served as the basis for the passage to more efficient housing estates built in modernistic forms (Figure 6). After 1958, the Athens Charter open-space urbanism was widely adopted in Romania (Lăzărescu, 1977, p. 65).

The large housing estates of the 1960s were the outcome of an efficient production line. First, there was an investment project. Then, adapted to it, a systematization sketch for the locality was drafted, followed by a detailed systematization plan for the housing estate. Finally, housing type designs were chosen from a catalog (Figure 7) and the estate was built. Technicaleconomic indexes-density, floor area, number of units, cost indexes, etc. - were decisive.

The idea of systematicity was entirely revived. A Systematization Handbook, edited in 1969, explained the hierarchic structure of the habitation zone: from the level of the apartment, whose functions were partially externalized and provided at a collective level, to the "housing group," which could share utilities such as a heating plant; to the "complex urban unit," a term that 


\section{COGITATIO}

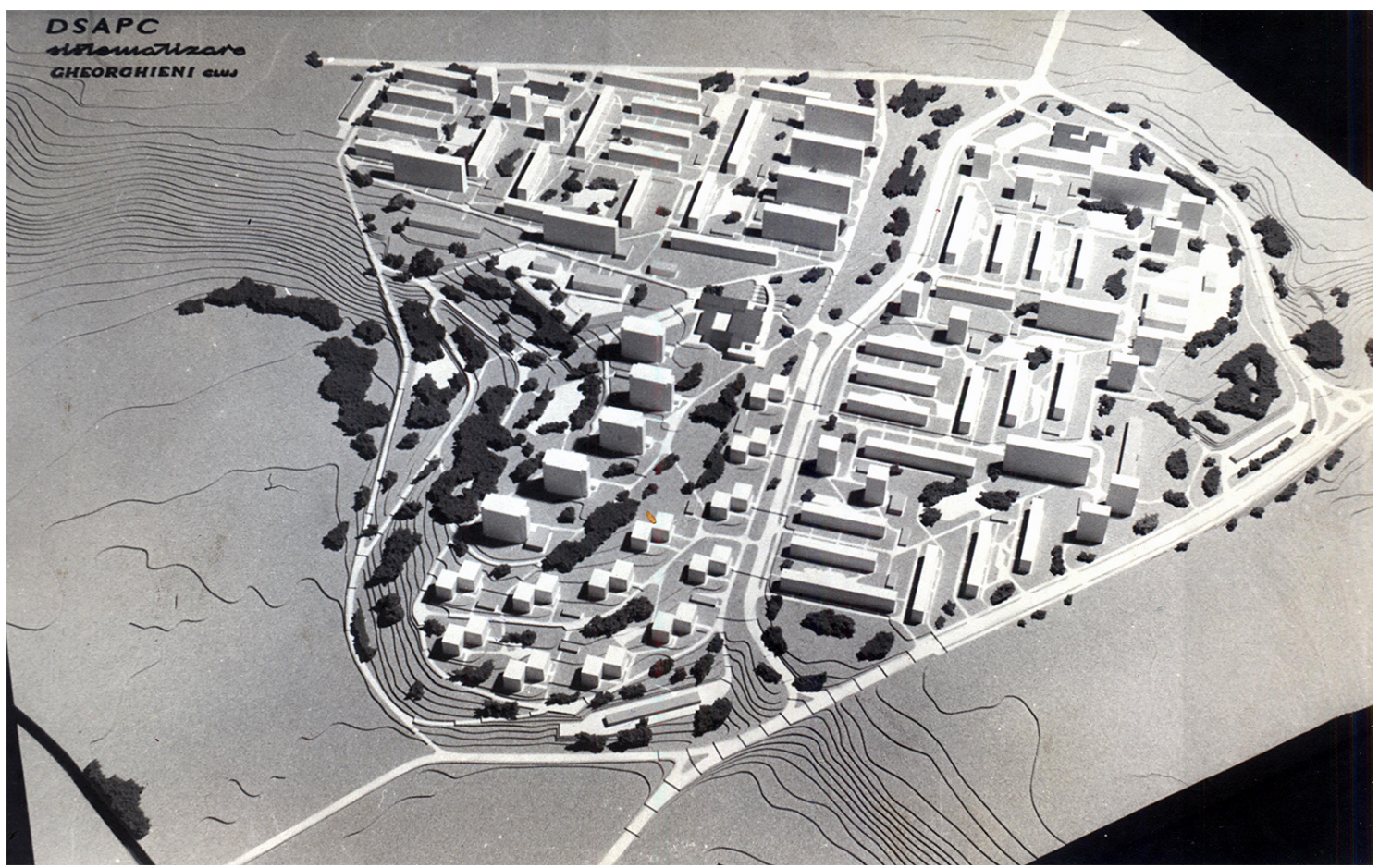

Figure 6. Model for Gheorgheni district (microraions I and II) by the architects Augustin Presecan, Vasile Mitrea, and Aurelian Buzuloiu, Cluj, 1964. Photo by N. Kulin. Source: Direction of Systematization, Architecture and Constructions Design of Cluj.

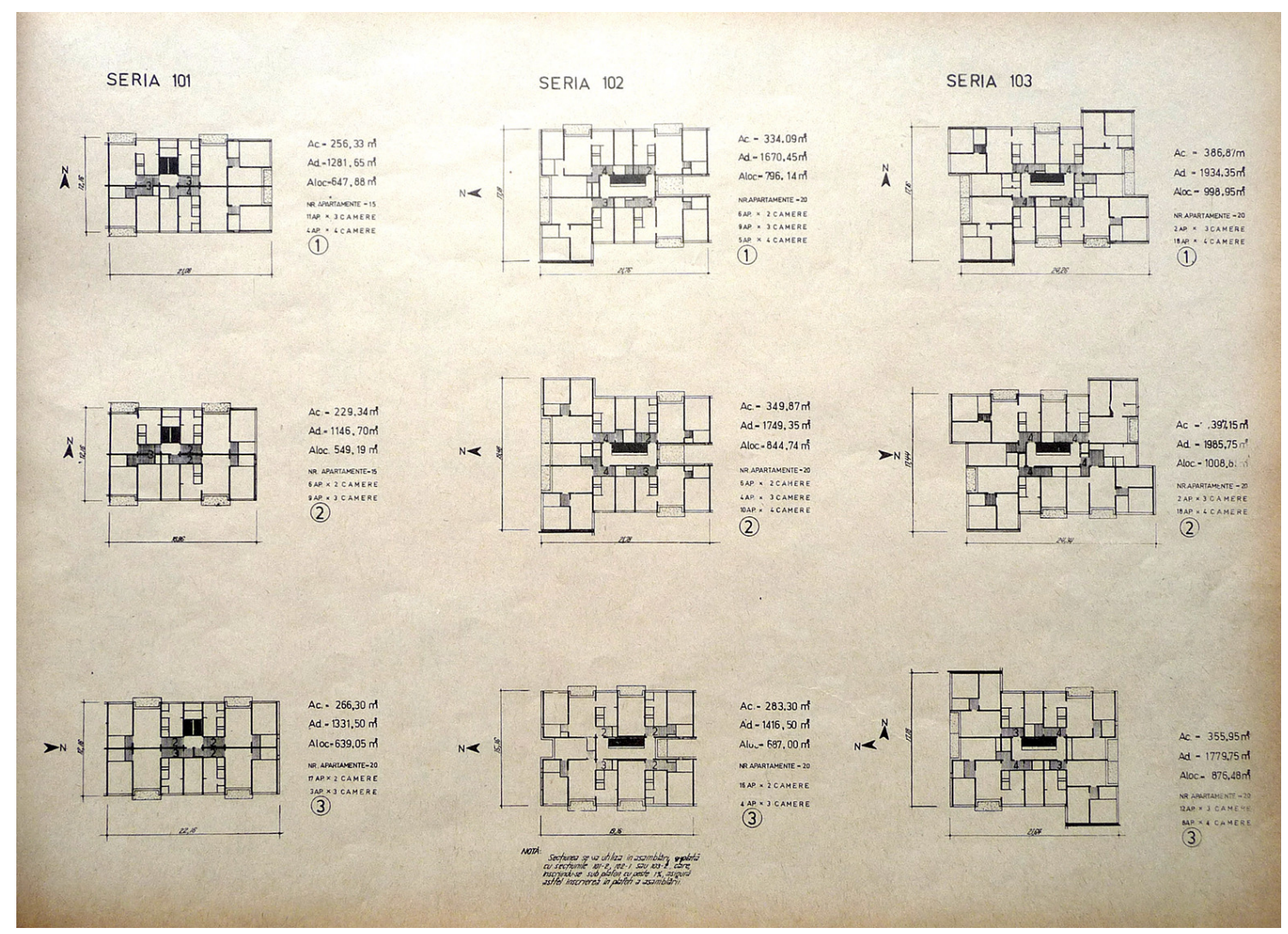

Figure 7. A plate from directive project no. 1361/1967 designed by Institutul de Proiectare pentru Construcții Tipizate (The Design Institute for Type Constructions). Source: The Institute for Studies and Projects for Systematization, Architecture and Typification (1971). 
had just replaced microraion (by name only, as principles remained the same); to a "complex" made of at least two of such units; to a "district" (cartier), comprising several complexes (Figure 8); to the locality, composed of a few districts; and finally to the system of localities (G. Chițulescu \& Rău, 1969, pp. 70-75). This all-scales abstract construct, along with modernistic architectural language, provided uniformity to mass housing developments in the entire country. The homogenization of the built environment throughout the national territory was achieved essentially through housing systematization.

\subsection{From Practice to Science to Political Instrument}

The late 1950s was the moment of "the leap from empiric urbanism to scientific urbanism" (Laurian, 1959, p. 47). From then on, a general belief in the efficiency of systematic methods prevailed. For architect Gustav Gusti, the "scientific fundament" of territorial organization was all about thinking in systems. Settlements were organized in an urban, rural, or mixed urban-rural interconnected "system of systems," incremental in size and complexity. Each city and village had an "optimal size" according to its role within this "system of complex territorial systems," which was a form of "guided and planned urbanization, proper to our country" (Gusti, 1967 , p. 39). For all its scientificity, systematization was politically directed.

Architect Gheorghe Sebestyen also remarked that the main change in systematization since the early 1960s was its transformation from a technical activity into a scientific one. The key in understanding this change, he claimed, lied in a new connotation of scientificity itself: "the scientific research of the future," that is, the "prospective character" of systematization (Sebestyen, 1974, p. 10). The idea that systematization must expand from spatial to temporal relevance was also stressed by sociologist Gheorghe Chepeș. The city was made of people and objects in correlation-a complex system of information and energy connections. Therefore, "according to systems theory," Chepeș (1971, p. 58) claimed, "prospective thinking" and "modern procedures of prognosis" should be used in systematization. However, he also concluded that the "regulator" of this complex system was eventually a "decision body."

The most advanced advocate of science in systematization was architect and professor Mircea Enache, who promoted mathematical instruments in planning. He referred to planning systems in the US and UKa change in inspiration sources that characterized the relative political liberalization of the late 1960s and early 1970s in Romania. The US was advancing new systems planning methodologies and the emerging field of computer science, of which Enache was a passionate supporter. He addressed the various terms for "systematization" and the differences between the practices they named. In the US, Enache explained, "sistematizare complexă" was called "comprehensive planning." "Strategic planning" (i.e., complex systematization) and "operational planning" (i.e., physical

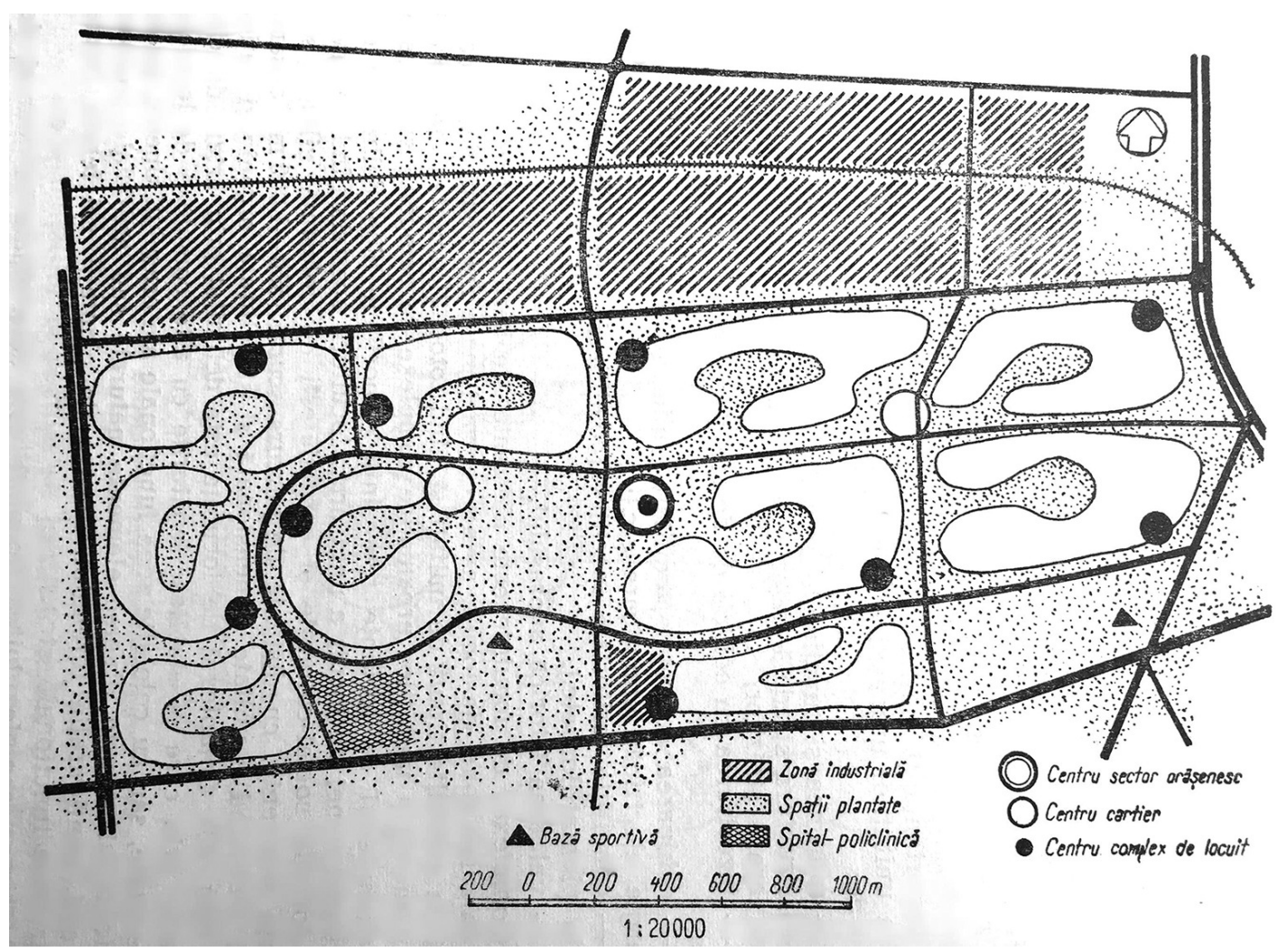

Figure 8. Scheme of housing district organization in complex urban units. Source: G. Chițulescu and Rău (1969, p. 72). 
systematization) were two different things. "Complex systematization" was strategy, oriented towards objectives in the long term, while current "operational systematization" was tactics, oriented towards realization. In Romania, urban systematization was strongly normative, physical, and strictly deterministic; therefore, it must be changed, by adopting more flexible instruments and methods of prognosis, simulation, statistics, and nuanced mathematical models, to be able to deal with open and uncertain horizons (Enache, 1974).

In the quest for scientificity, Romanian architects were in tune with a more general zeitgeist. By the mid-1970s, on both sides of the Iron Curtain, an acute awareness of the limitation of world resources led to a renewed technocratic belief in perfect scientific models and systems thinking (Kegler, 2017). However, what appealed to communist regimes in particular was the idea of total system control, i.e., systems theory as a means to effectively dictate over real space. In the USSR, for instance, the need for cost-effective housing engendered a discourse on cybernetics as mathematical meta-science, which was developed as the "science of cost-saving optimizations" and translated into comprehensive planning. It devised a "meta-scale approach," which led to the organization of the entire country as a centrally governable system of optimizable subsystems (Kurkovsky West, 2019).

For the Romanian communist regime, mathematical instruments and systems science did not serve for openended planning, but for legitimizing political decisions and increasing the control over the way to a predetermined future. The moment when architects' discourse on science reached the climax, around the mid-1970s, was also the moment when the Systematization Law (1974) set the definitive ways in which systematization would work from then on.

\subsection{Architecture, Urbanism, and Systematization}

When housing started being addressed as a mass phenomenon in the late 1950s, it was the moment of passage "from the architecture of the building to the architecture of the city" (Gusti, 1959, p. 33). This was another leap, in scale, from architecture to urbanism: urbanism seemed more important than architecture during the 1960s. Nevertheless, in Romania, urbanism was not a distinct profession and was practiced by architects. Urbanism was taught in architecture school (the Institute of Architecture Ion Mincu in Bucharest) and architects were more or less trained to act as urbanists too. However, they were not prepared specifically for the technical questions of systematization.

Systematization as a profession emerged in the early 1960s when the Institute of Constructions in Bucharest began training "systematization engineers." Formalized in this new academic program, systematization became a disciplinary field in its own right. Architects received it almost with "hostility," as an unwelcome "competition."
But the motivation of this program was precisely the fact that architects practicing urbanism were overwhelmed by the growing scale of infrastructure developments and new interventions in the territory (Vernescu, 1967).

Systematization was also taught in technical schools of architecture (a lower college specialization, preparing technicians to assist architects and engineers), with its own Systematization Handbook (G. Chițulescu \& Rău, 1969). The Handbook gave separate definitions to "systematization" and "urbanism," but also associated them inseparably. Both were academic disciplines, both were scientific, both were "concrete activities" concerned with the "creation of new cities and the transformation of the existing ones" (G. Chițulescu \& Rău, 1969, pp. 3-4). Urbanism was somehow broader because it included the operations of systematization, but also narrower because it was limited to the urban scale and systematization was not. However, the difference was by no means clear-cut, not least because both disciplines were still practiced mainly by architects. Not even the subtle distinctions that architect and professor of urbanism Alexandru Sandu developed in a later Lexicon (Sandu, 1988a, 1988b) - assigning urbanism mostly with culture and knowledge, and systematization with practice and action-really went beyond the idea of their major overlap.

In the mid-1970s, Gustav Gusti (1974, p. 20) defined systematization as the latest arrived in a series of disciplinary specializations. Depicting the successive emergence of architecture, urbanism, and systematization starting from constructions, he considered all four as having the same disciplinary rank. About a decade later, a Small Illustrated Lexicon of Systematization Notions (Cardaș, 1983) gave another explanation, in a diagram showing systematization as an intricate relationship between interventions at urban, regional, and territorial scales (Figure 9). The entire Small Lexicon itselfa book that was small only in format, but in content was so comprehensive that it included all imaginable notions of planning-bore witness that systematization had become an all-inclusive field, engulfing urbanism entirely, and even parts of architecture.

Nevertheless, architects remained prime actors in the otherwise multidisciplinary systematization projects. During the 1970s and 1980s, architects in Romania received diplomas awarded by the Ion Mincu Institute of Architecture (the only graduate school of architecture in Romania at the time), attesting their "specialization in architecture and systematization." Architecture, urbanism, and systematization together built up one syncretic profession of "architect." The architectural perspective upon all scales of spatial planning was thus provided by default.

\subsection{Full-Scale Totalitarian}

The Romanian Communist Party brought systematization to the center of its interests in 1967 (Ionescu, 1969, 

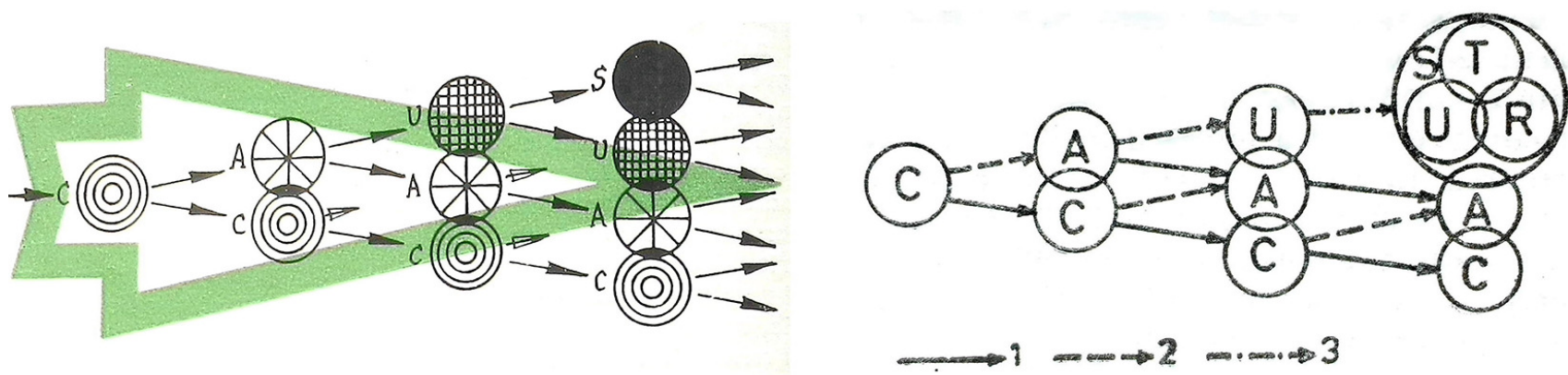

Figure 9. Diagrams of the relationship between constructions, architecture, urbanism, systematization, and urban, regional, and territorial scales. Sources: Gusti (1974, p. 20; left) and Cardaș (1983, p. 307; right).

p. 64). A formal political program of national systematization was launched in 1972. This program also recuperated the concept of "civic center" (Romanian Communist Party, 1972, pp. 476-498), which marked the shift in the power's interest towards being represented through architecture-just like during the late 1930s.

Housing concepts also changed. After a series of laws-Housing Law (1973), Systematization Law (1974), and Streets Law (1975)-higher density was imposed and open urbanism gave way to compact housing estates, specific to intensive urban growth. Slabs were dressed along streets (placare) and housing estates were composed in "precincts" (incinte; Lăzărescu, 1977, pp. 21, 65-66)-not unlike the former "cvartals" of the early 1950s. Housing systematization was also transformed by a renewed interest in architecture's monumental expression.

The most radical objective was the systematization of villages and the reorganization of the system of local- ities (Figure 10). Sub-optimal villages-too small, too sparse, and too many-were supposed to be phased out and the population moved into fewer compact localities, upgraded to a quasi-urban status, and endowed with new civic centers. This implied a redistribution of the population at a geographic scale and a redesign of the spatial structure of entire social systems into a hierarchy of dispersed centralities.

The analogy with Christaller's theory of central places (Pascariu, 2011) with its hierarchized geometric pattern ordering the system of settlements is indeed relevant. Similarities could be found even in more sinister implications, as Christaller initially applied this theory for dislocating the population in occupied Poland during World War II. With its Nazi past forgotten, the theory has been recuperated in the West in the late 1960s (Bustin, 2020), precisely at the time when the Thaw allowed Romanian architects to enjoy some western documentation. The Small Lexicon of Systematization Notions

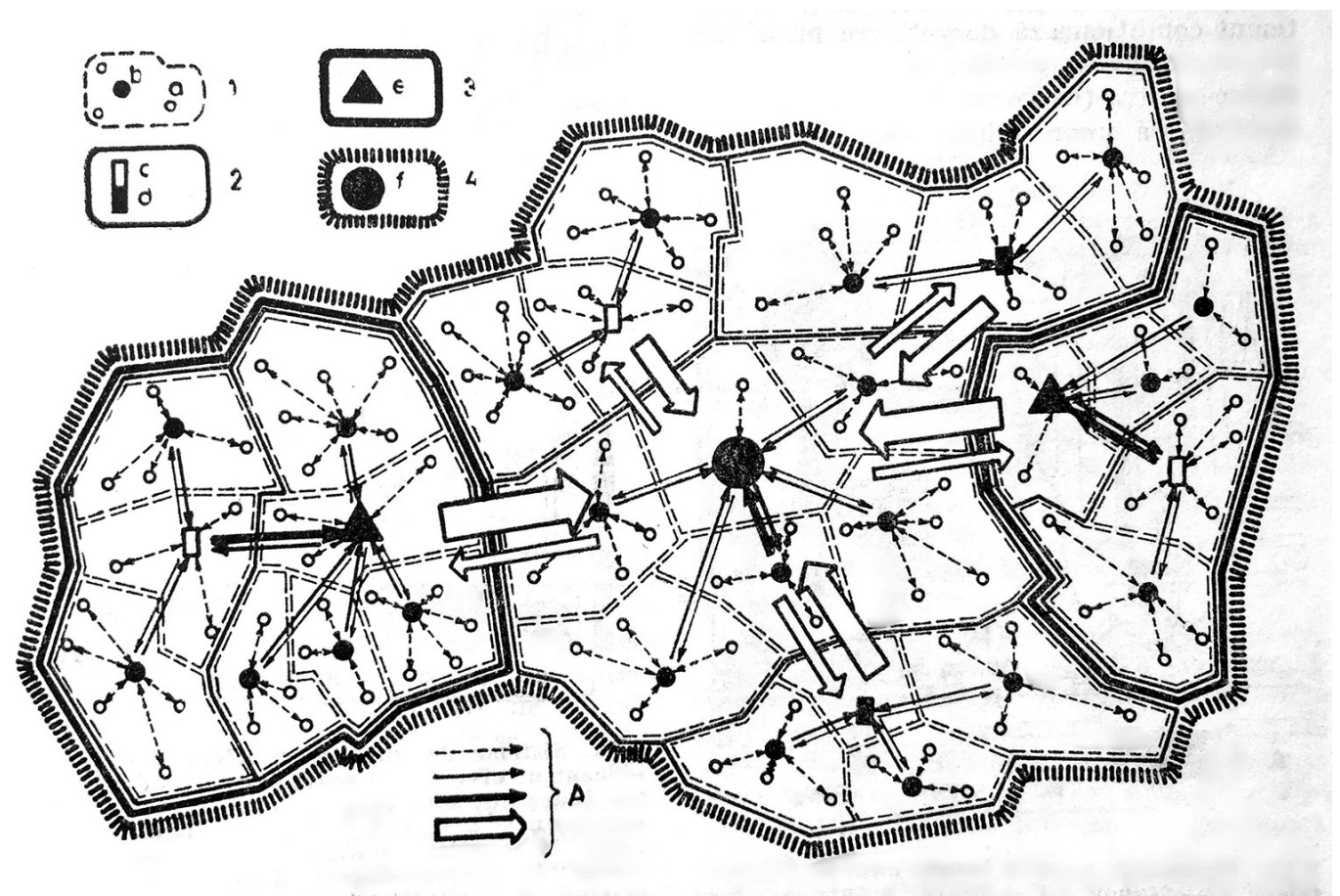

Figure 10. A system of localities diagram. Source: Cardaș (1983, p. 303). 
(Cardaș, 1983, p. 140) mentioned Christaller's "hexagonal theory." But Romanian systematization retained the idea of the top-down/bottom-up exchange structure between higher- and lower-ranked localities, rather than the "rings" of connectivity between equally ranked ones (Christaller, 1933/1966, pp. 224-225). While Christaller's theory stressed interconnectivity, Romanian systematization stressed hierarchy. Nevertheless, they shared a preference for graphic expressions - the aestheticization of the abstract spatial order-and also shared their significance: population control in the name of a geometrically balanced settlement system.

The radical restructuring of thousands of villages and towns was planned in Romania after the 1974 law, but it only started being enacted in the late 1980s. In 1986, 3,931 of the 13,123 existing villages were proposed to be demolished and the population relocated; however, only about six of them, in the proximity of Bucharest, have been razed, and 29 towns have been rebuilt at $90 \%$ (Fezi, 2013). Along with the demolition of the Bucharest historic center, this made Romanian systematization infamous worldwide.

The term and the extreme practices it stood for were among the first things abolished after 1990. Systematization as a field was officially renamed urbanism și amenajarea teritoriului (urban and territorial planning). Urbanism became independent from architecture after 1997, when an academic program training proper urban planners was created in a new Faculty of Urban Planning, at the (renamed) University of Architecture and Urban Planning Ion Mincu in Bucharest. A change in the planning paradigm occurred once Romania joined the liberal globalized world. Architects and urbanists are now able to pursue the most topical ideas of the contemporary zeitgeist.

Today, one of the most seductive ideas is the "system city." Cities and territories are now described as "complex systems," founded on "intelligent" infrastructural systems, and are addressed with "mathematical models of the processes of biological and natural systems" (Weinstock, 2013, pp. 17, 23, cover 4). Methods are borrowed from hard sciences dealing with complexity and adapted to the new digital paradigm. Globally interconnected computers are processing high-volume data and "the whole surface of our planet" is taken into consideration as one ecosystem. Moreover, "quasi-Orwellian operational models" observe cities through their "interconnected infrastructure systems, to facilitate their control" (Fournier, 2013, pp. 125, 128). In these contemporary forms of systematicity, digital tools are revolutionary, and terms are arguably different-but basic ideas are not.

\section{Conclusion}

This article tried to underline the importance of longtime perspectives. In addressing a key concept such as systematization, drawing its whole story was impor- tant for comprehending the continuity of its core ideas, but also understanding how these ideas evolved and were redefined, by each context the term emerged in. In Romania, systematization had two successive lives: before and after World War II. There were a few notions in systematization that traversed both periods: the urge of modernization, the look for efficiency through scientific methods and systemic thinking, the need for a reliable instrument to control spatial development, and the unitary coordination of spatial interventions throughout the country. The two climaxes in the life of systematization also looked similar: Each regime in its last and most dictatorial phase tried to enforce radical spatial change with maximum impact on all scales, in the name of systematization. Up to a point, history repeated itself. However, what is most striking in the long history of systematization is the great distance not between its meanings during the two periods, but between theory and real effects in each of them, between architects' intentions and what systematization became eventually.

Another point was the critical question of whether scientific and technocratic expertise, claiming the neutrality of its instruments, could ever be truly free from political interference. The article showed how in two different political regimes the result was arguably the same. The most common interpretation is that those in power confiscated the neutral technical instrument and (mis)used it. When historian Dennis Deletant (1995/2015, Chapter 8) drew a thorough political history of systematization under Ceaușescu's regime, for instance, he presented it as Ceaușescu's program entirely, remarking that he didn't leave any decisions to architects. Systematization appeared as just an instrument, which turned destructive in the hands of communist power. However, the fact that the professional expertise had nothing to do with it is not entirely true. The intrinsic disciplinary logic of formal scientification, plus the architecturalization and even aestheticization of planning, also contributed to what systematization would become. If we consider the long-time perspective moreover and address systematization also in contexts before and after the communist regime, we see that the very idea of systematization always assumes the entanglement with a power that could enact it-its geometric lines of force could always emerge only within a power field.

Last but not least, a crucial point was that systematization should be understood as a core concept of modern urbanism. Professing rationality, efficiency, abstraction, and rigorous geometric order, systematization was about 20th-century modernity in its outmost radical expression, as a way to achieving pure ideal forms of spatial organization: It was a concept of outright modernism. The fact that systematization began as a promise of modernization and progress and ended as an oppressive totalitarian tool, which had to be terminated, emulated modernism's evolution. Also, the certain fascination that systematization exerted was mostly at a discursive level. Most of the time, the rhetoric of systematization 
prevailed over real enactment; and when change was eventually imposed upon real space, the process became violent and unsustainable. This could be a warning for today's discourses of radical modernization. The terms in which the present-day paradigms of systematicity are expressed prove they are situated in continuity rather than in rupture with the radical discourses of modernization of the 20th century.

What history teaches us eventually is that terms can endure for a long time and adapt to renewed contexts. Words may vanish and the notions they name still survive. As conceptual tools, they bear the risks of becoming purposes in themselves and being misused. The term systematization, in Romania, paid the price for the misuse of the tools it named: The word was eradicated from the professional language. The top-down enforcement of its radical method into real space may be momentarily delegitimized too, but its basic idea, that our inhabited environments are best addressed as systems of interdependence, on all scales, has by no means been invalidated.

If we eventually try to dissect systematization terminologically, we may distinguish between the term, the concept, and the idea of systematization. Systematization as a term is quite transparent, with its etymology immediately graspable. Consequently, it is a word straightforwardly translatable, transferring almost as such through different languages and various disciplinary jargons. It is a word that is still alive and functional. Systematization as a concept (and what was developed here) is the meaning the term acquires in a specific context. The concept moves through scientific disciplines and professional practices, crossing specific cultures, instantiating itself in certain places and at certain moments in time. It denotes the search for systematicity, that is, the action of putting a coherent order into all things and addressing an entire "world" in its immeasurable complexity-but its actual meaning depends on the "world" that it engages in; in our case, it was the planning of the spatial environment of a country in a century. Because dealing with such complexity is a challenge that could never be fulfilled in its entirety, the concept of systematization is always specific and context dependent. The concept of systematization can be grasped only in variable local and temporal, and indeed partial, understandings. Finally, if we try to extract the idea of systematization-some constant meaning beyond any historical case, the essence of what systematization is-this could be to understand, find, and enhance the interconnectedness in all things. But then, nothing exists outside history. The idea behind the term could be articulated only from all its possible historical conceptualizations. This is what this article, with its idiosyncratic concept of systematization, contributed to.

\section{Acknowledgments}

This work was supported by the Israel Institute for Advanced Studies in Jerusalem. This publication is based upon work from COST Action, European Middle Class Mass Housing (MCMH-EU) CA 18137 supported by COST (European Cooperation in Science and Technology). www.cost.eu

\section{Conflict of Interests}

The author declares no conflict of interests.

\section{References}

Berindeiu, D. (1891). Bucureștii. Studiu istoric [Bucharest. Historic study]. Analele Arhitecturei, II(7), 130-139.

Bolomey, R., \& Davidescu, I. (1924). Concursul pentru sistematizarea orașului Belgrad [Competition for the systematization of the city of Belgrade]. Arhitectura, III, 20-22.

Bustin, R. (2020). From the archive: Christaller's central place theory. Teaching Geography, 45(1), 12-14.

Cardaș, M. (Ed.). (1983). Mic lexicon ilustrat al noțiunilor de sistematizare [Small illustrated lexicon of systematization notions]. Ed. Tehnică.

Chepeș, G. (1971). Reflecții ale unui sociolog pe marginea sistematizării ca disciplină și acțiune [A sociologist's reflections on systematization as discipline and action]. Arhitectura, XIX(1), 57-59.

Chițulescu, G., \& Rău, R. (1969). Sistematizare. Manual pentru elevii școlilor tehnice de arhitectură [Systematization. Handbook for the students of technical schools of architecture]. Editura Didactică și Pedagogică.

Chițulescu, T., Chițulescu, G., \& Gherghel, R. (Eds.). (1954). Manualul arhitectului proiectant. Volumul I [The handbook of the practicing architect. Volume I]. Ed. Tehnică.

Chițulescu, T., Chițulescu, G., \& Gherghel, R. (Eds.). (1958). Manualul arhitectului proiectant. Volumul III [The handbook of the practicing architect. Volume III]. Ed. Tehnică.

Christaller, W. (1966). Central places in Southern Germany. Prentice-Hall. (Original work published 1933)

Davidescu, I. (1936). Noțiuni de urbanism [Notions of urbanism]. Urbanismul, XIII(9/10), 379-423.

Davidescu, I. (1941). Istoricul urbanismului în România [History of urbanism in Romania]. Arhitectura, VII(1), 170-175.

Deletant, D. (2015). Ceaușescu and the Securitate: Coercion and dissent in Romania, 1965-1989. Routledge. (Original work published 1995)

Domhardt, K. S. (2012). The garden city idea in the CIAM discourse on urbanism: A path to comprehensive planning. Planning Perspectives, 27(2), 173-197.

Enache, M. (1974). Metoda în sistematizarea urbană. Punct de vedere [Method in urban systematization. Point of view]. Arhitectura, XXII(3), 12-15.

Enescu, I. D. (1933). Specificul urbanistic al capitalei [Urban specificity of the capital]. Arhitectura, 1933(1), 13-15. 
Fezi, B. A. (2013). De la systématisation de Bucarest à la destruction des villages roumains [From systematization of Bucharest to distruction of Romanian villages]. In Situ, 2013(21). https://doi.org/10.4000/ insitu.10390

Fournier, C. (2013). The city beyond analogy. Architectural Design, 83(4), 124-131. https://doi.org/ 10.1002/ad.1629

Gusti, G. (1959). Construcția de locuințe și urbanismul [Housing construction and urbanism]. Arhitectura $R$. P. R., VII(2), 33-34.

Gusti, G. (1967). Forme noi de așezare a populației în teritoriu [New forms of population settlement into the territory]. Arhitectura, XV(4), 38-39.

Gusti, G. (1974). Forme noi de așezare a populației în teritoriu. Studiu prospectiv de sistematizare macroteritorială [New forms of population settlement into the territory. Prospective study of macroterritorial systematization]. Ed. Tehnică.

Ionescu, G. (1969). Arhitectura în România, perioada anilor 1944-1969 [Architecture in Romania during the years of 1944-1969]. Ed. Academiei RSR.

Istituto Nazionale di Urbanistica. (1930). Statuto [Statute]. http://www.inu.it/wp-content/uploads/ bozza_statuto_Inu_1930.pdf

Kegler, K. R. (2017). Introduction: On systems and systems change. In Á. Morávansky \& K. R. Kegler (Eds), Re-scaling the environment. New landscapes of design 1960-1980 (Vol. 2, pp. 13-20). Birkhäuser.

Laurian, R. (1959). Pregătirea cadrelor de specialiști în urbanism [Preparing expert staff in urbanism]. Arhitectura R. P. R., VII(2), 47.

Lăzărescu, C. (1977). Urbanismul în România [Urbanism in Romania]. Ed. Tehnică.

Locar, M., \& Evolceanu, T. (1959). Reconstrucția socialistă a orașelor din Republica Populară Romînă [Socialist reconstruction of the cities in the Popular Republic of Romania]. Arhitectura R. P. R., VII(2), 5-7.

Marcu, D., Cantacuzino, G. M., Bolomey, R., Davidescu, I., \& Rădulescu, T. (1937). Planul director de sistematizare al Municipiului București [Director plan of systematization of the municipality of Bucharest]. Urbanismul, XIV(7/8), 293-310.

Ministers' Council of Romania. (1903). Lege pentru lucrările de amenagiare, executare, punere în aplicațiune a dispozițiunilor legei silvice și creațiunea șcólei speciale de silvicultură, 8 iunie 1883 [Law for planning, execution, application of the forestry law and creation of the special school of forestry, June 8, 1883]. In C. Hamangiu (Ed.), Codul General al României. Codurile și legile uzuale în vigóre, Vol. II, 1860-1903 [General Code of Law of Romania. The codes and laws in use and in effect, Vol. II, 1860-1903] (pp. 2029-2030). Editura Librăriei Leon Alcalay.

Mumford, E. (2018). Designing the modern city. Urbanism since 1850. Yale University Press.

National Institute of Urbanistics of Italy. (1932). Statu- tul Institutului Național Urbanistic Italian, 1930 [The statute of the National Institute of Urbanistics, 1930]. Urbanismul, IX(1/2), 35-36.

Opari, S. H. (1939). Construcții și realizări urbanistice ale Ținutului Bucegi [Constructions and urban achievements in Bucegi Land]. Arhitectura, V(3), 4-29.

Pascariu, G. (2011). Planificare teritorială în anii comunismului [Territorial planning in the communist years]. Urbanismul-Serie Nouă, 2011(7/8), 112-116.

Primăria Bucuresci. (1906, March 26). Concurs pentru facerea unui proiect general de sistematisarea Orașului Bucuresci [Competition for the making of a general systematization design for Bucharest City]. Monitorul Oficial.

Rădulescu, V. (1941). Istoricul și realizările arhitecturale în serviciile publice [History and architectural achievements in public services]. Arhitectura, VII(1), 116-119.

Romanian Communist Party. (1972). Conferința Națională a Partidului Comunist Român [The national conference of the Romanian Communist Party]. Editura Politică.

Sandu, A. (1974). Orașul și satul în contextul procesului de urbanizare [The city and the village in the context of urbanization process]. Arhitectura, XXII(3), 49-53.

Sandu, A. (1988a). Sistematizare. In S. Bălan \& N. Mihăilescu (Eds.), Lexicon de construcții și arhitectură [Lexicon of constructions and architecture] (Vol. III, pp. 321-322). Ed. Tehnică.

Sandu, A. (1988b). Urbanism. In S. Bălan \& N. Mihăilescu (Eds.), Lexicon de construcții și arhitectură [Lexicon of constructions and architecture] (Vol. III, pp. 505-506). Ed. Tehnică.

Sebestyen, G. (1974). Între sistematizarea de ieri și cea de mîine [Systematization between yesterday and tomorrow]. Arhitectura, XXII(3), 10-12.

Sfințescu, C. (1916). "Parcela" și "blocul" în constituirea orașelor [The "parcel" and the "block" in the making of cities]. Buletinul Societății Politehnice. https://pdfslide.net/documents/cincinat-sfintescuparcela-si-blocul-in-construirea-oraselor.html

Sfințescu, C. (1932). Învățământul urbanismului în străinătate și în România [Urbanism education abroad and in Romania]. Urbanismul, IX(11/12), 425-431.

Sfințescu, C. (1933a). Urbanistica generală [General urbanistics]. Urbanismul, $X(1 / 2,5 / 6)$. 17-88, 289-348.

Sfințescu, C. (1933b). Societatea comunală de locuințe eftine și realizările ei [The Communal Society of Low-cost Housing and its achievements]. Urbanismul, $X(5 / 6), 269-288$.

Sfințescu, C. (1934a). Orașe americane [American cities]. Urbanismul, XI(1/2), 32-53.

Sfințescu, C. (1934b). Urbanistica specială [Special urbanistics]. Urbanismul, $X I(1 / 2,3 / 4), 1-29,97-170$.

Sfințescu, C. (1938). Superurbanismul încadrat în stilul totalitar [Superurbanism framed in totalitarian style]. 
Urbanismul, XV(10/11/12), 341-348.

Sfințescu, C. (1939). Ruralismul în România și metoda de acțiune [Ruralism in Romania and action method]. Urbanismul, XVI(1/2/3), 33-41.

Sfințescu, C. (2015). Cum să privim chestiunea sistematizării Bucureștiului? [How to consider the question of Bucharest systematization?]. In Z. Rostás (Ed.), Între proiecții urbanistice și sărăcie letargică. Bucureștiul arhitecților și medicilor. [Between urban projections and letargic poverty. Architects' and doctors' Bucharest] (pp. 31-52). Editura Vremea.

Spiride, C. (1959). Sistematizarea teritorială [Territorial systematization]. Arhitectura R. P. R., VII(2), 28-30.

Stănculescu, F. (1925). Satele Noui Formate în legătură cu reforma agrară [New villages formed with the agrarian reform]. Arhitectura, IV, 28-29.

The Institute for Studies and Projects for Systematization, Architecture and Typification. (1971). Catalog de proiecte tip-locuințe [Catalogue of type designsHousing].

Udrea, A., Popescu, T., Calotă, I., \& Păun-Constantinescu, I. (Eds.). (2015). Cincinat Sfințescu. Începuturile urbanismului românesc [Cincinat Sfințescu. The beginnings of Romanian urbanism]. Editura Universitară Ion Mincu.

Vernescu, D. (1967). Rolul inginerilor în sistematizare
[Engineers' role in systematization]. Arhitectura, XV(4), 14-17.

Vîrtosu, G. (1936). Locuințe pentru populația nevoiașă și problema comasărilor [Housing for the poor and land consolidation question]. Urbanismul, XIII(9/10), 424-438.

Vîrtosu, G. (1937). Locuințe pentru populația nevoiașă și problema comasărilor [Housing for the poor and land consolidation question]. Urbanismul, XIV(1/2), 54-70.

Weinstock, M. (2013). System city: Infrastructure and the space of flows. Architectural Design, 83(4), 14-23. https://doi.org/10.1002/ad.1614

West, D. K. (2019). The cybernetic eye: Scientific planning in the Soviet Mikroraion. The Journal of Architecture, 24(5), 699-717.

Zamphiropol, A. (1934). Despre planul de sistematizare al Bucureștilor [About the systematization plan of Bucharest]. Arhitectura, 1934(1), 41-45.

Zamphiropol, A. (1935). Despre urbanism. Câteva principii despre întocmirea planurilor de sistematizare [About urbanism. Several principles of devising systematization plans]. Arhitectura, I(1), 4.

Zamphiropol, A. (1936). Urbanismul și prefacerea capitalei [Urbanism and the transformation of the capital city]. Arhitectura, II(5), 4-6.

\section{About the Author}

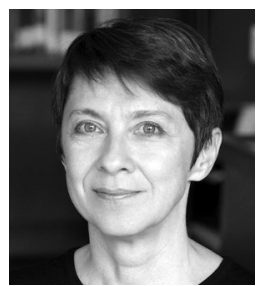

Dana Vais is a professor of architecture at the Faculty of Architecture and Urbanism of Technical University of Cluj-Napoca, Romania. Her research interests include architecture in the 20th century and housing history and theory. She is a member of the research group "Re-Theorizing Housing as Architecture" and a fellow of the Israel Institute for Advanced Studies in Jerusalem (2019-2020). 